\title{
Effect of Seed Priming on Plant Growth and Bulb Yield in Onion (Allium cepa L.)
}

\author{
B. Thejeshwini ${ }^{1 *}$, A. Manohar Rao ${ }^{2}$, M. Hanuman Nayak ${ }^{3}$ and Razia Sultana ${ }^{4}$ \\ ${ }^{1}$ Department of Vegetable Science, College of Horticulture, SKLTSHU, Rajendranagar, \\ Hyderabad-500030, India \\ ${ }^{2}$ Department of Horticulture, College of Agriculture, ${ }^{4}$ Department of Seed Science \& \\ Technology, Seed Research and Technology Centre, PJTSAU, Hyderabad, India \\ ${ }^{3}$ Department of Horticulture, Vegetable Research Station, ARI, SKLTSHU, Hyderabad, India \\ *Corresponding author
}

\section{A B S T R A C T}

\begin{tabular}{|l|}
\hline Key w or d s \\
Onion, Seed \\
priming, $\mathrm{GA}_{3}$, Bulb \\
yield
\end{tabular}

Seed priming is one of the pre-sowing seed management techniques where the seeds are partially soaked and subsequently dried back for invigorative effect that expresses on field emergence and extend up to yield. A field experiment was carried out to study the effect of different priming treatments on growth and bulb yield of onion during Rabi season. Seed of fresh and aged seed lots of onion cv. Agrifound Dark Red were subjected to hydro priming with distilled water for $24 \mathrm{hrs}\left(\mathrm{T}_{1}\right)$, halo priming with $3 \% \mathrm{KNO}_{3}$ for $12 \mathrm{hrs}\left(\mathrm{T}_{2}\right)$, osmo priming with PEG 6000 (-1.0 MPa) for $24 \mathrm{hrs}\left(\mathrm{T}_{3}\right)$, sand matric priming with $80 \%$ WHC for $24 \mathrm{hrs}\left(\mathrm{T}_{4}\right), \mathrm{GA}_{3}$ priming @ 100ppm for $6 \mathrm{hrs}\left(\mathrm{T}_{5}\right)$ and control $\left(\mathrm{T}_{6}\right)$. Significant variation recorded in fresh and aged seed lots and also among the seed priming treatments with respect to the growth and yield characters studied viz., field emergence percentage, plant height, number of leaves at 45, 75 and 95 DAT, equatorial bulb diameter, bulb height, average bulb weight and total bulb yield. It was observed that seed priming with $\mathrm{GA}_{3} @ 100 \mathrm{ppm}$ for 6 hrs has showed better effect in improving all the growth and bulb characters studied in both the fresh and aged seed lots over the control.

\section{Introduction}

Onion (Allium cepa L.) is an important vegetable crop grown and consumed widely across the world. India is the second largest producer of onion in the world next to China and ranks third in export of fresh onions. It is an indispensable vegetable in every kitchen and has gained the importance of a cash crop in recent years because of its very high export potential. Indian onions are famous for their pungency due to the presence of a volatile oil 'Allyl propyl disulphide' and are available round the year. It is used both in raw and mature bulb stage as vegetable and spices. It is valued for its characteristics flavour, pungent taste and medicinal importance (Padmini et al., 2007; Tyagi and Yadav, 2007). Use of quality seed is the most important factor as quality seeds ensure better germination as well 
as better yield. Onion seeds have poor longevity and storability which lose its viability very rapidly (Mumtaz Khan et al., 2004). Seed priming is one of the best methods which show rapid and uniform germination, synchrony in growth, development and increased yield. Seedling establishment is an important factor in bulb production of onion and largely depends on the seed germination and vigour. Seed quality enhancement is possible through various seed priming techniques including hydro priming, halo priming, osmo priming, thermo priming, solid matrix priming, and bio priming (Ashraf and Foolad 2005; Venkatasubramanian and Umarani, 2007).

Seed priming is commonly used to reduce the time between seed sowing, seedling emergence and also to overcome the constraints of low quality seed, untimely sowing, poor sowing techniques, inadequate soil moisture and adverse soil conditions (Parera and Cantliffe, 1994). The present study is planned and conducted to access the effect of different priming treatments on growth and bulb yield in onion.

\section{Materials and Methods}

The field study was carried out at Vegetable Research Station, ARI, SKLTSHU, Rajendranagar, Hyderabad from August, 2017 to February, 2018. The experiment was laid out in Randomized Block Design (Factorial) (RCBD) with three replications. The field data on growth parameters was recorded at 45, 75 and 95 DAT and yield attributing parameters data was recorded at the time of harvest. Equatorial diameter of bulb and bulb height was measured using digital Vernier Caliper.Data obtained were tabulated and subjected to statistical analysis by following the standard ANOVA method for Randomized Complete Block Design with Factorial concept (Panse and Sukhatme, 1985) and
Critical Difference (C.D.) were calculated wherever the results were significant.

The different priming treatments followed were, hydro priming, halo priming, osmo priming, sand matric priming and $\mathrm{GA}_{3}$ priming.

\section{Hydro priming}

Onion seeds of fresh and aged seed lots were primed on blotter paper wetted with distilled water for $24 \mathrm{hrs}$ at room temperature and shade dried back to their original moisture content.

\section{Halo priming}

Cleaned onion seeds were primed on blotter paper wetted with $3 \% \mathrm{KNO}_{3}$ salt solution for $12 \mathrm{hrs}$ at room temperature. The primed seed were shade dried at room temperature until the seed reaches to the original seed moisture content.

\section{Osmo priming}

Osmo priming was done using polyethylene glycol 6000 (PEG-6000) with an osmotic potential of $-1.0 \mathrm{MPa}$. The solution was prepared by mixing $27.3 \mathrm{~g}$ per $100 \mathrm{ml}$ of distilled water (Nienow and Bujaski, 1991). Onion seeds were soaked in PEG solution for $24 \mathrm{hrs}$ at room temperature along with aeration as suggested by (Jagosz, 2015) and then shade dried to original moisture content.

\section{Sand matric priming}

Onion seed of both seed lots were placed in perforated plastic covers. For this a tray $\left(25 \times 15 \times 10 \mathrm{~cm}^{3}\right.$ size $)$ with a sterilized sand of two $\mathrm{kg}$ quantity was taken and $246 \mathrm{ml}$ of distilled water per $\mathrm{kg}$ of sand was added to attain 80 per cent water holding capacity as suggested by Venkatasubramaniam and 
Umarani (2007). The seeds were primed in sand and retrieved after $24 \mathrm{hrs}$ and shade dried to original seed moisture content.

\section{GA3 priming}

Onion seeds of both the seed lots were primed on blotter paper wetted with $100 \mathrm{ppm}$ gibberellic acid solution for $6 \mathrm{hrs}$ at room temperature. They were then allowed to shade dry until the seed reaches its original seed moisture content.

\section{Results and Discussion}

The data on field emergence as influenced by the seed lots and priming treatments are presented in Table 1. Field emergence (\%) gives accurate and reproducible results in predicting the planting value under field condition. Significant variation was observed in the field emergence between fresh and aged seed lots and among seed priming treatments. A mean value of 82.33 and $70.11 \%$ field emergence in fresh and aged seed lots was recorded. Highest field emergence percentage was recorded in $\mathrm{GA}_{3}$ priming treatment with $80.50 \%$ followed by halo priming with $78.67 \%$ while, lowest was recorded in control with $72.33 \%$ of field emergence. Among the interactions, $\mathrm{S}_{1} \mathrm{~T}_{5}$ and $\mathrm{S}_{2} \mathrm{~T}_{5}\left(\mathrm{GA}_{3} @ 100\right.$ ppm for $6 \mathrm{~h}$ ) recorded highest field emergence percentage i.e., 86.67 and $74.33 \%$ in fresh and aged seed lots. Priming treatment activates the metabolic activity in the first phase of germination before sowing and hence provides added advantage of better emergence, growth and establishment of seedlings in the field (Vanangamudi and Kulandaivelu, 1989). These results are in conformity with Poonam et al., (2006) on partially aged sunflower seeds who reported best field emergence is achieved when seeds treated with $\mathrm{GA}_{3}$. Plant height: Significant variation in the plant height is noticed at 45, 75 and 95 days after transplanting between fresh and aged seed lots and among seed priming treatments (Table 2). At 45 days a mean plant height of $28.23 \mathrm{~cm}$ and $24.74 \mathrm{~cm}$, at 75 days i.e., $59.56 \mathrm{~cm}$ and $57.69 \mathrm{~cm}$ and at 95 DAT $54.62 \mathrm{~cm}$ and 51.57 $\mathrm{cm}$ was recorded in fresh seed lot and aged seed lots.

Plant height was highest in $\mathrm{GA}_{3}$ priming treatment with $27.51 \mathrm{~cm}$ at 45 DAT, $60.34 \mathrm{~cm}$ at 75 DAT and $55.41 \mathrm{~cm}$ at 95 DAT respectively. $\mathrm{T}_{2}$ with $27.26 \mathrm{~cm}$ at 45 DAT, $59.68 \mathrm{~cm}$ at $75 \mathrm{DAT}$ and also $\mathrm{T}_{3}$ at $75 \mathrm{DAT}$ i.e., $59.45 \mathrm{~cm}$ were on par with $\mathrm{GA}_{3}$ treatment. Lowest plant height was recorded in control $25.12 \mathrm{~cm}$ at 45 DAT, $56.13 \mathrm{~cm}$ at 75 DAT and $50.29 \mathrm{~cm}$ at 95 DAT respectively. Interaction varied significantly and the combinations $S_{1} T_{5}$ and $\mathrm{S}_{2} \mathrm{~T}_{5}$ recorded highest plant height i.e., $29.11 \mathrm{~cm} 25.91 \mathrm{~cm}$ at 45 DAT; $61.03 \mathrm{~cm}$ and $59.64 \mathrm{~cm}$ at 75 DAT and $57.29 \mathrm{~cm}$ and 53.53 $\mathrm{cm}$ at 95 DAT in both the fresh and aged seed lots.

Enhancement in the morphological characters may be due to $\mathrm{GA}_{3}$ which helps in breaking seed dormancy, promotes germination, internodal length and cell division in cambial zone and increases the size of leaves (Nalini Tiwari et al., 2001; Shukla et al., 2010).

Number of leaves: Significant variation in number of leaves per plant was noticed between fresh and aged seed lots and among the seed priming treatments (Table 3). At 45 days a mean number of leaves per plant of 5.94 and 4.88 , at 75 days 8.58 and 7.9 and at 95 DAT 8.51 and 7.75 was recorded in fresh and aged seed lots respectively. More number of leaves per plant was recorded in $T_{5}\left(\mathrm{GA}_{3}\right)$ priming treatment with 6.43 at $45 \mathrm{DAT}, 9.21$ at 75 DAT and 9.11 at 95 DAT. $\mathrm{T}_{2}$ treatment with 6.17 at 45 DAT 8.79 at 75 DAT and also $\mathrm{T}_{3} 8.66$ at 75 DAT were on par with $\mathrm{T}_{5}$ treatment respectively. Less number of leaves per plant was recorded in control 4.11 at 45 DAT, 6.81 at 75 DAT and 7.0 at 95 DAT 
respectively. Among the interactions, $\mathrm{S}_{1} \mathrm{~T}_{5}$ and $\mathrm{S}_{2} \mathrm{~T}_{5}$ recorded more number of leaves per plant i.e., 7 and 5.85 at 45 DAT; 9.47 and 8.95 at 75 DAT and 9.57 and 8.64 at 95 DAT in both the fresh and aged seed lots.

$\mathrm{GA}_{3}$ also stimulates hydrolytic enzymes that are needed for the degradation of the cells surrounding the radicle and thus speeds germination by promoting seedling elongation growth of cereal seeds (Rood et al., 1990). Seed priming with growth regulator increases the number of leaves Amin et al., (2007).
Significant variation in equatorial bulb diameter and bulb height is noticed between fresh and aged seed lots and among seed priming treatments (Table 4).

Equatorial bulb diameter $(\mathrm{cm})$ : A mean equatorial diameter of $6.09 \mathrm{~cm}$ and $5.59 \mathrm{~cm}$ was recorded in fresh and aged seed lots. Among the treatments, $\mathrm{T}_{5}$ recorded maximum equatorial diameter of $6.52 \mathrm{~cm}$ and $\mathrm{T}_{2}$ with $6.32 \mathrm{~cm}$ was on par with $\mathrm{T}_{5}$ followed by $\mathrm{T}_{3}$ with $5.82 \mathrm{~cm}$.

Table.1 Effect of seed priming on field emergence percentage in onion

\begin{tabular}{|l|c|c|c|}
\hline \multicolumn{1}{|c|}{ Treatment } & $\begin{array}{c}\text { Fresh seed } \\
\operatorname{lot}\left(\mathbf{S}_{\mathbf{1}}\right)\end{array}$ & $\begin{array}{c}\text { Aged seed } \\
\operatorname{lot}\left(\mathbf{S}_{\mathbf{2}}\right)\end{array}$ & Mean \\
\hline $\begin{array}{l}\mathbf{T}_{\mathbf{1}} \text {-Hydro } \\
\text { priming }\end{array}$ & 81.33 & 69.00 & $\mathbf{7 5 . 1 7}$ \\
\hline $\mathbf{T}_{\mathbf{2}}$-Halo priming & 85.00 & 72.33 & $\mathbf{7 8 . 6 7}$ \\
\hline $\mathbf{T}_{\mathbf{3}}$-Osmo priming & 83.00 & 70.00 & $\mathbf{7 6 . 5 0}$ \\
\hline $\mathbf{T}_{\mathbf{4}}$-Sand matric & 80.00 & 68.33 & $\mathbf{7 4 . 1 7}$ \\
\hline $\mathbf{T}_{\mathbf{5}}$-GA $\mathbf{3}$ priming & 86.67 & 74.33 & $\mathbf{8 0 . 5 0}$ \\
\hline $\mathbf{T}_{\mathbf{6}}$-Control & 78.00 & 66.67 & $\mathbf{7 2 . 3 3}$ \\
\hline Mean & $\mathbf{8 2 . 3 3}$ & $\mathbf{7 0 . 1 1}$ & \\
\hline & $\mathbf{S}$ & $\mathbf{T}$ & $\mathbf{S} \times \mathbf{T}$ \\
\hline SE(m) $\mathbf{5}$ & 0.24 & 0.41 & 0.58 \\
\hline CD at 5\% & 0.70 & 1.20 & 1.70 \\
\hline
\end{tabular}

Table.2 Effect of seed priming on plant height $(\mathrm{cm})$ at 45, 75 and 95 DAT in onion

\begin{tabular}{|c|c|c|c|c|c|c|c|c|c|}
\hline \multirow{2}{*}{ Treatment } & \multicolumn{3}{|c|}{ 45 DAT } & \multicolumn{3}{c|}{ 75 DAT } & \multicolumn{3}{c|}{ 95 DAT } \\
\cline { 2 - 11 } & $\mathbf{S}_{\mathbf{1}}$ & $\mathbf{S}_{\mathbf{2}}$ & $\mathbf{M e a n}$ & $\mathbf{S}_{\mathbf{1}}$ & $\mathbf{S}_{\mathbf{2}}$ & $\mathbf{M e a n}$ & $\mathbf{S}_{\mathbf{1}}$ & $\mathbf{S}_{\mathbf{2}}$ & $\mathbf{M e a n}$ \\
\hline $\mathbf{T}_{\mathbf{1}}$ & 28.34 & 24.48 & $\mathbf{2 6 . 4 1}$ & 60.10 & 58.22 & $\mathbf{5 9 . 1 6}$ & 54.63 & 51.45 & $\mathbf{5 3 . 0 4}$ \\
\hline $\mathbf{T}_{\mathbf{2}}$ & 28.91 & 25.61 & $\mathbf{2 7 . 2 6}$ & 60.78 & 58.59 & $\mathbf{5 9 . 6 8}$ & 56.17 & 52.66 & $\mathbf{5 4 . 4 1}$ \\
\hline $\mathbf{T}_{\mathbf{3}}$ & 28.51 & 24.82 & $\mathbf{2 6 . 6 7}$ & 60.37 & 58.52 & $\mathbf{5 9 . 4 5}$ & 55.22 & 51.63 & $\mathbf{5 3 . 4 3}$ \\
\hline $\mathbf{T}_{\mathbf{4}}$ & 27.74 & 24.14 & $\mathbf{2 5 . 9 4}$ & 58.41 & 56.53 & $\mathbf{5 7 . 4 7}$ & 53.38 & 50.64 & $\mathbf{5 2 . 0 1}$ \\
\hline $\mathbf{T}_{\mathbf{5}}$ & 29.11 & 25.91 & $\mathbf{2 7 . 5 1}$ & 61.03 & 59.64 & $\mathbf{6 0 . 3 4}$ & 57.29 & 53.53 & $\mathbf{5 5 . 4 1}$ \\
\hline $\mathbf{T}_{\mathbf{6}}$ & 26.73 & 23.50 & $\mathbf{2 5 . 1 2}$ & 57.60 & 54.67 & $\mathbf{5 6 . 1 3}$ & 51.04 & 49.54 & $\mathbf{5 0 . 2 9}$ \\
\hline $\mathbf{M e a n}$ & $\mathbf{2 8 . 2 3}$ & $\mathbf{2 4 . 7 4}$ & & $\mathbf{5 9 . 7 1}$ & $\mathbf{5 7 . 6 9}$ & & $\mathbf{5 4 . 6 2}$ & $\mathbf{5 1 . 5 7}$ & \\
\hline & $\mathbf{S}$ & $\mathbf{T}$ & $\mathbf{S} \times \mathbf{T}$ & $\mathbf{S}$ & $\mathbf{T}$ & $\mathbf{S} \times \mathbf{T}$ & $\mathbf{S}$ & $\mathbf{T}$ & $\mathbf{S} \times \mathbf{T}$ \\
\hline SE(m)+ & 0.08 & 0.15 & 0.21 & 0.20 & 0.35 & 0.49 & 0.19 & 0.32 & 0.46 \\
\hline $\mathbf{C D}$ at 5\% & 0.25 & 0.44 & 0.62 & 0.58 & 1.01 & 1.43 & 0.55 & 0.95 & 1.35 \\
\hline
\end{tabular}


Table.3 Effect of seed priming on number of leaves at 45, 75 and 95 DAT in onion

\begin{tabular}{|c|c|c|c|c|c|c|c|c|c|}
\hline \multirow{2}{*}{ Treatment } & \multicolumn{3}{|c|}{ 45 DAT } & \multicolumn{3}{c|}{ 75 DAT } & \multicolumn{3}{c|}{ 95 DAT } \\
\cline { 2 - 12 } & $\mathbf{S}_{\mathbf{1}}$ & $\mathbf{S}_{\mathbf{2}}$ & $\mathbf{M e a n}$ & $\mathbf{S}_{\mathbf{1}}$ & $\mathbf{S}_{\mathbf{2}}$ & $\mathbf{M e a n}$ & $\mathbf{S}_{\mathbf{1}}$ & $\mathbf{S}_{\mathbf{2}}$ & $\mathbf{M e a n}$ \\
\hline $\mathbf{T}_{\mathbf{1}}$ & 5.78 & 4.67 & $\mathbf{5 . 2 3}$ & 8.67 & 8.01 & $\mathbf{8 . 3 4}$ & 8.25 & 7.45 & $\mathbf{7 . 8 5}$ \\
\hline $\mathbf{T}_{\mathbf{2}}$ & 6.35 & 5.99 & $\mathbf{6 . 1 7}$ & 8.83 & 8.75 & $\mathbf{8 . 7 9}$ & 9.17 & 8.38 & $\mathbf{8 . 7 7}$ \\
\hline $\mathbf{T}_{\mathbf{3}}$ & 6.26 & 4.74 & $\mathbf{5 . 5 0}$ & 8.81 & 8.51 & $\mathbf{8 . 6 6}$ & 8.80 & 7.83 & $\mathbf{8 . 3 2}$ \\
\hline $\mathbf{T}_{\mathbf{4}}$ & 5.74 & 4.33 & $\mathbf{5 . 0 3}$ & 7.95 & 7.34 & $\mathbf{7 . 6 4}$ & 8.12 & 7.39 & $\mathbf{7 . 7 5}$ \\
\hline $\mathbf{T}_{\mathbf{5}}$ & 7.00 & 5.85 & $\mathbf{6 . 4 3}$ & 9.47 & 8.95 & $\mathbf{9 . 2 1}$ & 9.57 & 8.64 & $\mathbf{9 . 1 1}$ \\
\hline $\mathbf{T}_{\mathbf{6}}$ & 4.51 & 3.72 & $\mathbf{4 . 1 1}$ & 7.77 & 5.84 & $\mathbf{6 . 8 1}$ & 7.16 & 6.84 & $\mathbf{7 . 0 0}$ \\
\hline $\mathbf{M e a n}$ & $\mathbf{5 . 9 4}$ & $\mathbf{4 . 8 8}$ & & $\mathbf{8 . 5 8}$ & $\mathbf{7 . 9 0}$ & & $\mathbf{8 . 5 1}$ & $\mathbf{7 . 7 5}$ & \\
\hline & $\mathbf{S}$ & $\mathbf{T}$ & $\mathbf{S} \times \mathbf{T}$ & $\mathbf{S}$ & $\mathbf{T}$ & $\mathbf{S} \times \mathbf{T}$ & $\mathbf{S}$ & $\mathbf{T}$ & $\mathbf{S} \times \mathbf{T}$ \\
\hline $\mathbf{S E}(\mathbf{m}) \mathbf{\pm}$ & 0.08 & 0.13 & 0.19 & 0.12 & 0.20 & 0.29 & 0.09 & 0.16 & 0.23 \\
\hline $\mathbf{C D} \mathbf{a t} \mathbf{5 \%}$ & 0.02 & 0.39 & 0.55 & 0.35 & 0.60 & 0.85 & 0.27 & 0.48 & 0.67 \\
\hline
\end{tabular}

Table.4 Effect of seed priming on equatorial diameter $(\mathrm{cm})$ and bulb height $(\mathrm{cm})$ in onion

\begin{tabular}{|c|c|c|c|c|c|c|}
\hline Treatment & $\begin{array}{c}\text { Fresh seed } \\
\operatorname{lot}\left(\mathbf{S}_{1}\right)\end{array}$ & $\begin{array}{c}\text { Aged seed } \\
\operatorname{lot}\left(\mathbf{S}_{2}\right)\end{array}$ & Mean & $\begin{array}{c}\text { Fresh seed } \\
\operatorname{lot}\left(\mathbf{S}_{1}\right)\end{array}$ & $\begin{array}{c}\text { Aged seed } \\
\operatorname{lot}\left(\mathbf{S}_{2}\right)\end{array}$ & Mean \\
\hline $\mathrm{T}_{1}$-Hydro priming & 5.85 & 5.63 & 5.74 & 6.43 & 5.90 & 6.17 \\
\hline $\mathbf{T}_{2}$-Halo priming & 6.63 & 6.00 & 6.32 & 6.65 & 6.10 & 6.38 \\
\hline$T_{3}$-Osmo priming & 5.90 & 5.75 & 5.82 & 6.53 & 5.98 & 6.26 \\
\hline $\mathbf{T}_{4}$-Sand matric & 5.74 & 5.29 & 5.51 & 6.19 & 5.21 & 5.70 \\
\hline $\mathbf{T}_{5}-\mathbf{G A}_{3}$ priming & 6.85 & 6.19 & 6.52 & 6.74 & 6.56 & 6.65 \\
\hline$T_{6}-$ Control & 5.58 & 4.70 & 5.14 & 5.18 & 4.57 & 4.87 \\
\hline Mean & 6.09 & 5.59 & & 6.29 & 5.72 & \\
\hline & $\mathbf{S}$ & $\mathbf{T}$ & $\mathbf{S} \times \mathbf{T}$ & $\mathbf{S}$ & $\mathbf{T}$ & $\mathbf{S} \times \mathbf{T}$ \\
\hline $\mathrm{SE}(\mathrm{m}) \pm$ & 0.08 & 0.13 & 0.19 & 0.09 & 0.16 & 0.23 \\
\hline CD at $5 \%$ & 0.23 & 0.40 & 0.56 & 0.28 & 0.48 & 0.68 \\
\hline
\end{tabular}

Table.5 Effect of seed priming on average weight of bulb $(\mathrm{g})$ and total bulb yield $\left(\mathrm{t} \mathrm{ha}^{-1}\right)$ in onion

\begin{tabular}{|l|c|c|c|c|c|c|}
\hline Treatment & $\begin{array}{c}\text { Fresh seed } \\
\text { lot }\left(\mathbf{S}_{\mathbf{1}}\right)\end{array}$ & $\begin{array}{c}\text { Aged seed } \\
\text { lot }\left(\mathbf{S}_{\mathbf{2}}\right)\end{array}$ & Mean & $\begin{array}{c}\text { Fresh seed } \\
\left.\text { lot } \mathbf{( S}_{\mathbf{1}}\right)\end{array}$ & $\begin{array}{c}\text { Aged seed } \\
\text { lot }\left(\mathbf{S}_{\mathbf{2}}\right)\end{array}$ & Mean \\
\hline $\mathbf{T}_{\mathbf{1}}$-Hydro priming & 99.07 & 96.43 & $\mathbf{9 7 . 7 5}$ & 27.41 & 25.00 & $\mathbf{2 6 . 2 1}$ \\
\hline $\mathbf{T}_{\mathbf{2}}$-Halo priming & 103.45 & 101.10 & $\mathbf{1 0 2 . 2 8}$ & 30.60 & 26.54 & $\mathbf{2 8 . 5 7}$ \\
\hline $\mathbf{T}_{\mathbf{3}}$-Osmo priming & 101.47 & 98.91 & $\mathbf{1 0 0 . 1 9}$ & 29.40 & 25.92 & $\mathbf{2 7 . 6 6}$ \\
\hline $\mathbf{T}_{\mathbf{4}}$-Sand matric & 97.24 & 94.77 & $\mathbf{9 6 . 0 1}$ & 28.95 & 22.18 & $\mathbf{2 5 . 5 6}$ \\
\hline $\mathbf{T}_{\mathbf{5}}$-GA priming & 105.35 & 102.95 & $\mathbf{1 0 4 . 1 5}$ & 32.68 & 29.34 & $\mathbf{3 1 . 0 1}$ \\
\hline $\mathbf{T}_{\mathbf{6}}$-Control & 95.76 & 93.05 & $\mathbf{9 4 . 4 1}$ & 24.77 & 20.30 & $\mathbf{2 2 . 5 4}$ \\
\hline Mean & $\mathbf{1 0 0 . 3 9}$ & $\mathbf{9 7 . 8 7}$ & & $\mathbf{2 8 . 9 7}$ & $\mathbf{2 4 . 8 8}$ & \\
\hline & $\mathbf{S}$ & $\mathbf{T}$ & $\mathbf{S} \times \mathbf{T}$ & $\mathbf{S}$ & $\mathbf{T}$ & $\mathbf{S} \times \mathbf{T}$ \\
\hline SE(m)+ & 0.23 & 0.40 & 0.57 & 0.20 & 0.35 & 0.49 \\
\hline CD at 5\% & 0.68 & 1.18 & 1.68 & 0.59 & 1.03 & 1.45 \\
\hline
\end{tabular}


Minimum equatorial diameter was recorded in unprimed seeds with $5.14 \mathrm{~cm}$. Interaction varied significantly and $\mathrm{S}_{1} \mathrm{~T}_{5}$ and $\mathrm{S}_{2} \mathrm{~T}_{5}$ recorded maximum equatorial diameter i.e., $6.85 \mathrm{~cm}$ and $6.19 \mathrm{~cm}$ in both the fresh and aged seed lots. $\mathrm{S}_{1} \mathrm{~T}_{2}$ with an equatorial diameter of $6.63 \mathrm{~cm}$ was on par with $\mathrm{S}_{1} \mathrm{~T}_{5}$ combination. Bulb height $(\mathrm{cm})$ : A mean bulb height of $6.29 \mathrm{~cm}$ and $5.72 \mathrm{~cm}$ was recorded in fresh and aged seed lots. $\mathrm{T}_{5}$ treatment recorded maximum bulb height of $6.65 \mathrm{~cm}$ and $\mathrm{T}_{2}$ with $6.38 \mathrm{~cm}$ and also $\mathrm{T}_{3}$ with $6.26 \mathrm{~cm}$ were on par with $\mathrm{T}_{5}$ treatment. Minimum bulb height was recorded in unprimed seeds with $4.87 \mathrm{~cm}$. Among the interactions, $\mathrm{S}_{1} \mathrm{~T}_{5}$ and $\mathrm{S}_{2} \mathrm{~T}_{5}$ recorded maximum bulb height i.e., $6.74 \mathrm{~cm}$ and 6.56 $\mathrm{cm}$ in both the fresh and aged seed lots. $\mathrm{S}_{1} \mathrm{~T}_{2}$ $\left(3 \% \mathrm{KNO}_{3}\right.$ for $12 \mathrm{~h}$ ) with a bulb height of $6.65 \mathrm{~cm}$ and $\mathrm{S}_{1} \mathrm{~T}_{3}$ (PEG 6000, -1.0 MPa for $24 \mathrm{~h}$ ) with $6.53 \mathrm{~cm}$ and also $\mathrm{S}_{1} \mathrm{~T}_{1}$ combination with $6.43 \mathrm{~cm}$ were on par with $\mathrm{S}_{1} \mathrm{~T}_{5}$ combination respectively. These results are in accordance with Devarajuet al., (2011) who reported that priming treatments showed significant effect on enhancement of field performance like plant height, number of leaves, equatorial and polar diameter of bulbs, etc. $\mathrm{KNO}_{3}$ stands next to gibberellic acid in the seedling performance.

Average weight of bulb (g): Average weight of bulbs in fresh (100.39 g) and aged seed lot $(97.87 \mathrm{~g})$ showed significant variation. The seed priming treatments were found to be significant (Table 5). The treatment $\mathrm{GA}_{3} @$ $100 \mathrm{ppm}$ recorded maximum average bulb weight i.e., $104.15 \mathrm{~g}$; followed by halo priming with $102.28 \mathrm{~g}$. Minimum average bulb weight was recorded in control treatment with $94.41 \mathrm{~g}$. Combinations $\mathrm{S}_{1} \mathrm{~T}_{5}$ and $\mathrm{S}_{2} \mathrm{~T}_{5}$ recorded maximum average bulb weight i.e., $105.35 \mathrm{~g}$ and $102.95 \mathrm{~g}$ in both the fresh and aged seed lots.

Total bulb yield $\left(\mathrm{t} \mathrm{ha}^{-1}\right)$ : There is significant variation in total bulb yield for the fresh seed lot $\left(28.97 \mathrm{t} \mathrm{ha}^{-1}\right)$ and aged seed lot $(24.88 \mathrm{t}$ $\left.\mathrm{ha}^{-1}\right)$. The seed treatments significantly differed for total bulb yield (Table 5). $\mathrm{T}_{5}$ $\left(\mathrm{GA}_{3} @ 100 \mathrm{ppm}\right)$ recorded highest total bulb yield of 31.01t ha ${ }^{-1}$ followed by $\mathrm{T}_{2}$ and $\mathrm{T}_{3}$ with 28.57 and $27.66 \mathrm{t} \mathrm{ha}^{-1}$ respectively. Among the interactions, $\mathrm{S}_{1} \mathrm{~T}_{5}$ and $\mathrm{S}_{2} \mathrm{~T}_{5}$ (GA $@ 100$ ppm) recorded highest total bulb yield of $32.68 \mathrm{t} \mathrm{ha}^{-1}$ and $29.34 \mathrm{t} \mathrm{ha}^{-1}$ in both the fresh and aged seed lots. It was followed by $\mathrm{S}_{1} \mathrm{~T}_{2}\left(3 \% \mathrm{KNO}_{3}\right.$ for $\left.12 \mathrm{~h}\right)$ with $30.60 \mathrm{tha}^{-1}$ and $\mathrm{S}_{1} \mathrm{~T}_{3}$ (PEG 6000, -1.0 MPa for $24 \mathrm{~h}$ ) with $29.40 \mathrm{t} \mathrm{ha}^{-1}$ respectively.

The yield increase was due to the increase in bulb size and weight. Enhanced yield by the use of $\mathrm{GA}_{3}$ was also reported by Pramanik et al., (2015) in sesame. In onion among the yield components, bulb diameter and bulb weight had maximum contribution towards onion bulb yield (Singh, 2001). Jagadish (1993) in onion cv. Pusa red noted increased plant stand, growth and number of bulbs than control in seeds treated with $\mathrm{GA}_{3}$.

In conclusion, the results revealed that priming of seeds also has the impact on yield characters of onion and $\mathrm{GA}_{3}$ treatment @ 100 ppm for $6 \mathrm{hrs}$ showed better performance over other treatments. It can be concluded that seed priming with $\mathrm{GA}_{3} @ 100$ ppm for 6 hrs or halo priming with $3 \% \mathrm{KNO}_{3}$ for $12 \mathrm{hrs}$ will help in enhancing the growth and yield attributing characters in onion.

\section{References}

Amin, A. A., EL-Sh. M. Rashad, and H.M.H. EL-Abagy., 2007. Physiological effect of indole - 3 - butyric acid and salicylic acid on growth, yield and chemical constituents of onion. Plants Journal of Applied Sciences Research, Vol.: 3(11), pp. 1554-1563.

Ashraf, M., Foolad, M.R., 2005. Pre-sowing seed treatment-a shotgun approach to improve germination growth and crop 
yield under saline and non-saline conditions. Advances in Agronomy. 88: 223-271.

Borowski, E., and Michałek, S. 2006. The effect of seeds conditioning on emergence and early growth of onion and carrot seedlings. Annales Universitatis Mariae CurieSkolodowska Sectio EEE, Horticultura. 16:119-129.

Devaraju, P. J., Nagamani, S., VeereGowda, R., Yogeesha, H.S., Gowda, R., Nagaraju, K.S., and Shashidhara, N. 2011. Effect of chemo priming on plant growth and bulb yield in onion, International Journal of Agriculture, Environment and Biotechnology. 4(2): 121-123.

Jagadish, G.V., 1993. Seed storability, ageing and effect of pre-sowing treatment on the performance of some vegetable crops. M.Sc. (Agri.) Thesis, University of Agricultural Sciences, Dharwad.

Jagosz, B., 2015. Improving onion seed germination using priming treatments. Infra and eco of rurare. 4:1437-1447.

Mumtaz khan, M., Javed Iqbal, M., Abbas, M., Raza, H., Waseem, R., and Arshad, A., 2004. Loss of vigour and viability in aged onion (Allium cepa L.) seeds. International Journal of Agriculture and Biology. 6 (4): 708-71.

Nalini Tiwari, Poonam Singh, C., Lal, P. K.,Katiyar., and Vaish, C. P., 2001. Effect of pre-sowing seed treatment on germination, growth and yield of onion (Allium cepa L.). Seed Research. Vol.: 29 (2), pp.238-239.

Nienow, A.W., and Bujaski, W., 1991. Large scale osmotic priming of onion seeds; a comparison of different strategies for oxygenation. Scientia Horticulturae. 46: 13-24.

Padmini, K., Gowda, R.V., and Naik, L.B., 2007. Studies on parental synchronization in flowering for hybrid seed production in onion (Allium cepa L.) Journal of Horticultural Science and Biotechnology. 2(1): 47-49.

Panse, V. G., and Sukhatme., 1985. Statistical methods for agricultural workers. Indian Council of Agriculture Research, New Delhi. p. 134-192.

Parera, C. A., and Cantliffe, D. J., 1994.Presowing seed priming. Horticulture Review. 16: 109-141.

Poonam Kumar, A., Bajpai, V. P., Singh, C. B., and Jataw, A. L., 2006. Effect of pre-treatment on partially aged seeds of sunflower (Helianthus annuus L.) for germination, vigour and seedling growth. XII National Seed Seminar on Prosperity through Quality Seed. pp. 130: 24-26.

Pramanik, K., Adhikari, A., Bera, A.K., and Mandal, B., 2015.Effect of seed priming and mulching on growth and productivity of rain-fed sesame (Sesamum indicum L.) during summer season. International Journal of Bioresource Science, 2:1.

Rood, S.B., Buzzell, R. I., Major, D.J., Pharis, R.P., 1990. Gibberellins and heterosis in maize: quantitative relationship. Crop Science. 30: 281-6.

Singh, N., 2001. In: Handbook of Horticulture. ed. Chadha, K.L, ICAR, New Delhi. pp. 428-430.

Shukla N., Mondal, S., Dikshit, S.N., Trivedi, J., Tamrakar, S., and Sharma, P., 2010. Effect of different concentrations of $\mathrm{GA}_{3}$ and NAA and their methods of application on growth and yield of onion (Allium cepa L.) Progressive Horticulture. Vol.: 42(1), pp.111-113.

Tyagi, A.K., and Yadav, S.K., 2007. Effect of growth regulators on growth and yield of onion (Allium cepa L.) cv. Pusa Red. Plant Archives. 7(1): 371-372.

Vanangamudi, K., and Kulandaivelu, R., 1989.Presowing seed treatment for 
dryland farming. Seeds \& Farms. 15(910): 22.

Venkatasubramanian, A., and Umarani, R. 2007. Evaluation of seed priming methods to improve seed performance of tomato (Lycopersicon esculentum), eggplant (Solanum melongena) and chilli (Capsicum annum). Seed Science and Technology. 35(2): 487-493.

\section{How to cite this article:}

Thejeshwini, B., A. Manohar Rao, M. Hanuman Nayak and Razia Sultana. 2019. Effect of Seed Priming on Plant Growth and Bulb Yield in Onion (Allium cepa L.). Int.J.Curr.Microbiol.App.Sci. 8(01): 1242-1249. doi: https://doi.org/10.20546/ijcmas.2019.801.131 